\title{
PENGGUNAAN MEDIA SOSIAL PADA MAHASISWA UNIVERSITAS KRISTEN PETRA SURABAYA
}

\author{
Vita Monica ${ }^{1 *}$, Regina Bella Rosari ${ }^{2}$ \\ 1,2 Program Studi Ilmu Komunikasi, Fakultas Ilmu Komunikasi \\ Universitas Kristen Petra \\ Jl. Siwalankerto 121-131, Surabaya 60236, INDONESIA \\ *Penulis korespondensi; E-mail: vita.monica@petra.ac.id
}

\begin{abstract}
ABSTRAK
Di tengah kemajuan zaman dan pertumbuhan teknologi, fungsi media massa mulai dilakukan media sosial. Hal ini dipengaruhi oleh berkembang pesatnya beragam jenis media sosial serta fitur-fiturnya. Sebagian besar pengguna media sosial adalah generasi milenial. Salah satu anggota generasi milenial dan pengguna aktif media sosial adalah mahasiswa, termasuk mahasiswa Universitas Kristen Petra. Penelitian dengan metode survei ini bertujuan mengetahui penggunaan media sosial Facebook, Twitter, Instagram, YouTube, dan LinkedIn oleh 225 mahasiswa Universitas Kristen Petra. Melalui hasil riset tersebut, diketahui mayoritas mahasiswa menggunakan media sosial Instagram. Instagram digunakan untuk mendapatkan informasi, mencari hiburan, menambah networking, serta menambah ilmu.
\end{abstract}

Kata kunci: Media sosial; mahasiswa; survei

\begin{abstract}
In the midst of the times and technological growth, the function of mass media began to be carried out by social media. This is influenced by the rapid development of various types of social media and its features. Most social media users are millennials. One of the millennial generation members and active users of social media are students, including Petra Christian University students. This study is using survey method, aims to determine using of Facebook, Twitter, Instagram, YouTube, and LinkedIn by 225 Petra Christian University students. From this study is known, the majority of students use Instagram. They used Instagram to get information, find entertainment, add networking, and increase knowledge.
\end{abstract}

Keywords: Social media; student, survey

\section{PENDAHULUAN}

Ilmu Komunikasi telah mengalami perubahan yang cukup signifikan, salah satu penyebabnya adalah perkembangan teknologi komunikasi dan informasi. Penggunaan media massa sebagai sumber informasi telah bergeser ke media sosial. Bahkan jika dikaitkan dengan bidang Public Relations, promosi dan iklan lebih banyak memanfaatkan media sosial disbandingkan dengan media tradisional. Lebih dari itu, pola interaksi sosial pun ikut berubah.

Internet merupakan produk teknologi yang banyak dimanfaatkan masyarakat. Sebagai produk teknologi, maka internet dapat memunculkan jenis interaksi sosial baru yang berbeda dengan interaksi sosial sebelumnya. Jika pada masa lalu masyarakat berinteraksi secara face to face communication, maka dewasa ini masyarakat berinteraksi di dunia maya atau melalui sosial online (Alyusi, 2016, p.1).
Seiring dengan perkembangannya, internet telah dimanfaatkan untuk berbagai kegiatan. Pengguna internet pun semakin bertambah setiap tahunnya. Kemudahan penggunaan internet membuat semakin banyak orang menggunakannya untuk kebutuhan sehari-hari. Dengan menggunakan internet berbagai hal dapat dilakukan, muncullah istilah "Dunia dalam genggaman". Media sosial adalah salah satu bentuk dari media yang memanfaatkan internet dan banyak digunakan oleh masyarakat.

Internet dan media sosial menyebabkan terjadinya pergeseran fungsi media massa. Di tahun 2007, Nurudin memaparkan sepuluh fungsi utama media massa, yaitu informasi, hiburan, persuasi, transmisi budaya, mendorong kohesi sosial, pengawasan, korelasi, pewarisan sosial, melawan kekuasaan dan kekuatan represif, serta menggugat hubungan trikotomi. Apabila disederhanakan, fungsi media massa secara umum adalah informasi, pendidikan, dan hiburan (p.63-93). 
Pencarian informasi telah bergeser dari media massa menjadi media sosial, salah satunya menggunakan aplikasi Twitter. Meskipun memiliki banyak kelemahan, media sosial tetap digunakan masyarakat untuk memperoleh informasi yang terbaru. Masyarakat juga menggunakan media sosial untuk mempelajari sesuatu, bahkan banyak komunitas yang memanfaatkan media sosial untuk berbagi ilmu. Aplikasi yang bisa digunakan untuk belajar adalah YouTube dan Facebook. YouTube juga menjadi pilihan dalam mencari hiburan dan salah satu kelebihannya adalah masyarakat dapat menentukan sendiri jenis hiburan apa yang ingin dinikmati. Hal ini sesuai hasil penelitian yang menunjukkan platform media sosial yang paling sering digunakan oleh masyarakat. Platform media sosial yang sering digunakan masyarakat Indonesia adalah YouTube (88\%), Facebook (81\%), Instagram (80\%), Twitter (52\%), dan LinkedIn (33\%). Angka tersebut merupakan persentase dari keseluruhan pengguna internet di Indonesia (Indonesia digital 2019: Media sosial, n.d.).

Pada tahun 2014, hanya terdapat 1,857 juta pengguna media sosial. Jumlah pengguna media sosial ini terus mengalami peningkatan setiap tahunnya. Hingga saat ini, sebanyak $45 \%$ populasi dunia merupakan pengguna media sosial. Menurut data 'We are Social' sampai dengan 25 Januari 2019, tiga platform media sosial dengan pengguna terbanyak adalah Facebook (2,271 juta pengguna), YouTube (1,9 juta pengguna), dan Instagram (1 juta pengguna) ("Digital in 2019", n.d.).

Pengguna media sosial yang terus bertambah setiap tahunnya ini dapat dimanfaatkan berbagai pihak, mulai perusahaan, organisasi, media hingga lembaga pemerintah. Agar pemanfaatannya sesuai sasaran, maka perlu diketahui karakteristik pengguna media sosial tersebut. Berdasarkan hasil riset yang dipublikasikan We Are Social pada Januari 2019, mayoritas pengguna media sosial di Indonesia adalah penduduk berusia 18-24 tahun dan 25-34 tahun. Jumlah pengguna media sosial pada masing-masing kelompok usia tersebut mencapai 33\%. Pada usia 18-24 tahun, $18 \%$ pengguna media sosial adalah laki-laki dan $15 \%$ pengguna lainnya adalah perempuan. Sedangkan, pada usia 25-34 tahun, 19\% pengguna adalah laki-laki dan 14\% sisanya perempuan (Indonesia digital 2019: Media sosial, n.d).

Dari hasil penelitian tersebut dapat diketahui bahwa rentang usia 18-34 tahun adalah mayoritas pengguna media sosial. Golongan usia ini adalah golongan usia produktif yang sedang dalam masa bekerja. Dengan kesibukan setiap harinya, golongan usia ini masih memiliki waktu menggunakan media sosial untuk berbagai kegiatan. Hal tersebut dapat dilihat dari hasil penelitian berikut. Di level dunia, masyarakat Indonesia menempati peringkat ketiga yang paling sering menggunakan media sosial, dengan durasi 3 jam 22 menit. (Orang Indonesia peringkat 3 dunia yang paling sering bermedsos, May 2, 2015).

Salah satu kelompok yang berada pada rentang usia 18-34 tahun adalah generasi milenial, yang. berprofesi sebagai siswa, mahasiswa, pekerja, bahkan orang tua tunggal. Generasi milenial tidak bisa lepas dari perangkat mobile untuk pencarian informasi, pembelian online, dan berinteraksi dengan brand atau produk. Dalam hidup sehari-harinya, generasi milenial mengutamakan identitas dan pengalaman sosial, tertarik dan akan menyebarkan konten yang autentik. Dilihat dari cara menerima upaya pemasaran, generasi milenial tidak tertarik dengan cara hard selling dan yang berorientasi pada perusahaan (Taher, October 20, 2017).

Ciri-ciri tersebut dapat ditemukan pada salah satu profesi generasi milenial, yaitu mahasiswa. Umumnya, mahasiswa di Indonesia berusia 18-24 tahun. Media sosial tak pernah terlepas dari aktivitas sehariharinya. Beragam jenis media sosial yang ada saat ini seolah telah 'menyihir' para mahasiswa terus mengikuti perkembangan tren media sosial terbaru. Tak terkecuali, mahasiswa Universitas Kristen Petra.

Universitas Kristen Petra merupakan sebuah universitas swasta di Surabaya yang berdiri pada tahun 1961. Di tahun 2018, Universitas Kristen Petra meaih akreditasi institusi A dan anugerah Perguruan Tinggi Unggulan dari Lembaga Layanan Pendidikan Tinggi Wilayah VII (UK Petra raih akreditasi institusi A dan anugerah kampus unggulan, December 4, 2018). Hingga saat ini, Universitas Kristen Petra memiliki tujuh fakultas dan 26 program studi untuk program S1 (Student, n.d.). Total, terdapat sekitar 8,427 mahasiswa dan 300 dosen aktif di Universitas Kristen Petra (Universitas Kristen Petra, n.d.)

Mahasiswa merupakan publik terbesar dari Universitas Kristen Petra. Menjadi tugas penting untuk selalu menjaga arus komunikasi bagi sebuah universitas dengan mahasiswanya. Media sosial dapat menjadi salah satu alternatif untuk menjalin komunikasi dengan publik sasaran. Khususnya organisasi yang memiliki publik sasaran dengan jumlah yang besar dan memiliki karakteristik yang berbeda-beda seperti Universitas Kristen Petra. Oleh sebab itu perlu 
diketahui pola penggunaan media sosial dari mahasiswa agar pemanfaat media sosial oleh Universitas Kristen Petra dapat tepat guna dan bermanfaat.

Tujuan penelitian ini adalah mengetahui penggunaan media sosial pada mahasiswa Universitas Kristen Petra Surabaya. Penggunaan media sosial tersebut nantinya akan bermanfaat bagi universitas untuk memilih media yang sesuai sehingga arus komunikasi dapat tepat sasaran dan bermanfaat bagi kedua belah pihak. Selain itu hasil penelitian ini dapat menjadi dasar dalam pembentukan strategi komunikasi bagi Universitas Kristen Petra dengan mahasiswanya.

\section{TINJAUAN PUSTAKA}

\subsection{Public Relations}

Menurut Cutlip (2007, p.6), public relations adalah fungsi manajemen yang membangun dan mempertahankan hubungan yang baik dan bermanfaat antara organisasi dengan publik yang memengaruhi kesuksesan atau kegagalan organisasi. Sebagian besar orang berpikir, Public Relations hanya mempromosikan perusahaan. Padahal, seorang Public Relations juga terlibat dalam upaya memastikan publik memiliki pandangan yang tepat terkait organisasi. Dengan kata lain, Public Relations merupakan upaya terencana dan berkelanjutan untuk membangun dan memelihara niat baik serta memahami organisasi dengan publicnya (Theaker, 2001, p.4).

Harris (1991) dalam bukunya 'Marketer's Guide to Public Relations', memaparkan praktik-praktik PR dalam kegiatan pemasaran. Oleh karena itu, di dalam buku tersebut, Harris memberikan penekanan terhadap pembagian dua bagian Public Relations: Corporate Public Relations (CPR) dan Marketing Public Relations (MPR). Praktisi CPR akan bekerja pada bidang media, investor, pemerintah, relasi dengan komunitas, komunikasi internal, advokasi, dan public affairs. Dengan kata lain, CPR cenderung lebih mementingkan hubungan perusahaan dengan publik non-pelanggannya Sedangkan, Praktisi MPR akan lebih mendorong komunikasi dua arah dengan semua publik perusahaan, tidak hanya pelanggan dan pelanggan potensial (Harris, 1991).

\subsection{Marketing Public Relations}

Istilah Marketing Public Relations pertama kali diperkenalkan Thomas L. Harris (1991). MPR didefinisikan sebagai proses perencanaan dan evaluasi, yang mendorong penjualan dan pelanggan melalui penyampaian informasi yang kredibel dan impresi yang mengidentifikasi perusahaan dan produknya sebagai kebutuhan serta perhatian pelanggan. Bahkan, menurut Kotler dalam Ruslan (2002, p.254), MPR juga memberi nilai tambah produk melalui kemampuan yang unik untuk menunjukkan kredibilitas pesan produk. Penekanan MPR terletak pada pemberian informasi serta peningkatan pengetahuan tentang produk atau jasa agar dampaknya lebih besar dan lebih diingat pelanggan (Abadi, 1994).

Dalam buku "Essentials of Marketing Communications" edisi ketiga, Blythe (2006) menyatakan empat buah aktivitas marketing public relations, yaitu:

1. Sales Promotion

Sales promotion terdiri atas rangkaian taktik dan teknik pemasaran yang didesain dengan kerangka strategi pemasaran untuk menambah nilai produk dan jasa. Tujuannya, peningkatan penjualan secara drastis pada periode waktu tertentu.

2. Branding and Product Labelling

Branding adalah proses menambahkan nilai produk pada pengemasan, nama merek, promosi, dan posisi dalam pikiran pelanggan. Sedangkan, product labelling merupakan pemberian nama pada pengemasan produk. Keduanya merupakan elemen sentral dari upaya perusahaan mengenalkan identitas dirinya.

\section{Exhibitions}

Sebagai tempat bertemu dan pertukaran informasi antara penjual dan calon pelanggan, pameran adalah cara ampuh menjangkau sejumlah besar pelanggan potensial.

\section{The Internet and World Wide Web}

Internet dan world wide web (www) menjadi alat komunikasi sekaligus penyedia akses untuk para pelanggan mengetahui informasi, dokumen, pesan komersial, situs belanja virtual, papan buletin, dan sumber informasi lainnya terkait perusahaan ataupun produknya.

\subsection{Media Sosial}

Media sosial adalah cara komunikasi yang baru dan alat kolaborasi aktif yang memungkinkan banyak jenis interaksi yang sebelumnya tidak tersedia pada orang-orang pada umumnya (Brogan, 2010). Dalam bukunya yang berjudul 'What is Social Media?", Mayfield (2008), menyatakan bahwa media sosial adalah media online yang memiliki karakteristik:

1. Partisipasi atau keikutsertaan. Media sosial menyajikan kontribusi berupa konten, dan pengguna media sosial yang tertarik akan memberikan umpan balik 
2. Keterbukaan. Hampir semua media sosial memungkinkan terjadinya umpan balik dan partisipasi para penggunanya.

3. Percakapan. Dengan media sosial, terjadi percakapan dua arah antara penggunanya.

4. Komunitas. Komunitas dan komunikasi antar pengguna yang efektif akan terbentuk lebih cepat dengan media sosial.

5. Keterhubungan. Sebagian besar jenis media sosial berkembang karena dapat saling terhubung.

Semakin lama, jumlah media sosial selalu bertambah. Namun, pada dasarnya terdapat tujuh jenis media sosial (Mayfield, 2008):

1. Social Networking

Pada media sosial dengan jenis social networking, pengguna dapat membuat halaman pribadi dan terhubung dengan pengguna lainnya untuk berkomunikasi serta berbagi konten. Contohnya, Facebook, Path, dan MySpace.

2. Blog

Blog mudah dikenali sebagai jurnal online yang memuat konten sebagai posting.

3. Wiki

Wiki memungkinkan para penggunanya berkolaborasi untuk menambah ataupun mengedit informasi. Contohnya adalah Wikipedia.

4. Podcast

Podcast merupakan file audio dan video yang tersedia dengan berlangganan melalui suatu layanan, seperti Apple iTunes.

5. Forum

Melalui forum, pengguna dapat berdiskusi secara online seputar topik dan minat tertentu.

6. Komunitas konten

Komunitas yang mengatur dan membagikan jenis konten tertentu dengan bentuk yang paling populer adalah YouTube.

7. Microblogging

Social networking yang dikombinasikan dengan blogging serta menghasilkan sejumlah kecil konten yang didistribusikan secara online. Contohnya, Twitter.

Selain jenis media sosial yang dijelaskan Mayfield (2008), Tim Pusat Humas Kementerian Perdagangan RI juga memaparkan beberapa jenis aplikasi media sosial, yaitu:

1. Aplikasi media sosial berbagi video, contohnya YouTube, Vimeo, dan Daily Motion.

2. Aplikasi media sosial mikroblog, contohnya Twitter dan Tumblr.

3. Aplikasi media sosial berbagi jaringan sosial, contohnya Facebook, Google Plus, dan Path

4. Aplikasi berbagi jaringan profesional, contohnya LinkedIn, Scribd, dan Slideshare
5. Aplikasi manajemen Twitter, contohnya TweetDeck,

6. Aplikasi berbagi foto, contohnya Pinterest, Picasa, Flickr, dan Instagram.

Kehadiran media sosial ini membawa dampak pada berbagai aspek. Kehadiran media sosial pada aspek jurnalisme memungkinkan para pengguna memproduksi hingga mendistribusikan sendiri melalui media sosial atau user-generated content (Gilmor, 2004). Apalagi, media sosial mampu memfasilitasi "kecepatan" serta jangkauan wilayah yang luas. Media sosial juga menyediakan keberagaman jenis konten, mulai dari teks, audio, visual, dan audio-visual (Nasrullah, 2015).

Tabel 1. Perbandingan Media Sosial dan Media Massa

\begin{tabular}{|c|c|c|}
\hline & Media Massa & Media Sosial \\
\hline Khalayak & $\begin{array}{l}\text { - Sebagai audiens } \\
\text { - Keterbatasan } \\
\text { wilayah dan } \\
\text { jangkauan media }\end{array}$ & $\begin{array}{l}\text { - Produser dan } \\
\text { konsumen informasi } \\
\text { - Media beragam dan } \\
\text { tidak terbatas geografis }\end{array}$ \\
\hline $\begin{array}{l}\text { Kecepatan } \\
\text { Transmisi } \\
\text { Informasi }\end{array}$ & $\begin{array}{l}\text { - Bergantung jalur } \\
\text { distribusi, } \\
\text { transmisi, dan } \\
\text { luas wilayah }\end{array}$ & $\begin{array}{l}\text { - Tidak terbatas platform } \\
\text { dan wilayah }\end{array}$ \\
\hline $\begin{array}{l}\text { Jenis } \\
\text { Informasi }\end{array}$ & $\begin{array}{l}\text { - Informasi sesuai } \\
\text { jenis media } \\
\text { (cetak, audio, } \\
\text { audio-visual) }\end{array}$ & $\begin{array}{l}\text { - Informasi beragam, } \\
\text { namun hanya sekilas }\end{array}$ \\
\hline $\begin{array}{l}\text { Ke- } \\
\text { lengkapan } \\
\text { Informasi }\end{array}$ & $\begin{array}{l}\bullet \text { Usur } 5 \mathrm{~W}+1 \mathrm{H} \\
\text { lengkap }\end{array}$ & $\begin{array}{l}\text { - Unsur } 5 \mathrm{~W}+1 \mathrm{H} \\
\text { cenderung tidak } \\
\text { lengkap } \\
\text { - Diperlukan konfirmasi } \\
\text { dan penggabungan } \\
\text { informasi lainnya }\end{array}$ \\
\hline $\begin{array}{l}\text { Akses } \\
\text { terhadap } \\
\text { Informasi }\end{array}$ & $\begin{array}{l}\text { - Memerlukan } \\
\text { media khusus } \\
\text { - Akses informasi } \\
\text { terbatas, } \\
\text { bergantung pada } \\
\text { jumlah media } \\
\text { yang diakses dan } \\
\text { dilanggan }\end{array}$ & $\begin{array}{l}\text { - Dapat diakses pada } \\
\text { media sosial tersebut, } \\
\text { timeline, atau } \\
\text { penyebaran di media } \\
\text { sosial. }\end{array}$ \\
\hline $\begin{array}{l}\text { Etika dan } \\
\text { Hukum }\end{array}$ & $\begin{array}{l}\text { - Institusi media } \\
\text { dilindungi hukum } \\
\text { dan bekerja } \\
\text { dengan etika } \\
\text { - Penanggung } \\
\text { jawab individu } \\
\text { dan institusi jelas }\end{array}$ & $\begin{array}{l}\text { - Tanggung jawab } \\
\text { sepenuhnya pada } \\
\text { individu sebagai } \\
\text { pengguna }\end{array}$ \\
\hline
\end{tabular}

Sumber: Nasrullah, 2015, p.159-p.160 
Selain pada bidang jurnalisme, kehadiran media sosial dan inovasi di internet juga membawa dampak terhadap praktik di bidang Public Relations yang selama ini digunakan. Misalnya, kemampuan media sosial mencakup pengguna sebagai individu yang berbeda-beda: antarindividu (one-to-one), individu ke massa (one-to-many), ataupun massa ke massa lain (many-to-many). Kemudian, media sosial menawarkan pula adanya jangkauan media sosial yang luas dan jaringan pengguna yang jauh lebih besar untuk menjalin kesepahaman antara organisasi dan masyarakat. Pengguna media sosial juga dapat menjadi corong bagi organisasi Public Relations untuk menjaga dan mengantisipasi kemungkinan terjadinya krisis komunikasi. Oleh karena itu, diperlukan pula perubahan mendasar terhadap konsep dan praktik Public Relations. Perubahan ini mesti dipahami setiap individu di dalam organisasi tanpa terkecuali (Nasrullah, 2015).

\section{METODE}

Penelitian ini merupakan penelitian deskriptif dengan pendekatan kuantitatif. Penelitian deskriptif menyajikan gambaran yang spesifik tentang situasi, penataan sosial, atau hubungan, yang menghasilkan gambaran terperinci atas pertanyaan penelitian (Neuman, 2013). Berlandas sifat positivistik, penelitian kuantitatif dimanfaatkan untuk meneliti serta menganalisis bentuk data kuantitatif atau statistik (Sugiyono, 2013). Metode yang digunakan dalam penelitian ini adalah survei. Pada metode ini, data dikumpulkan melalui kuesioner dengan tujuan memperoleh informasi tentang sejumlah responden yang dianggap mewakili populasi tertentu (Kriyantono, 2008, p.68).

Dari keseluruhan anggota populasi, peneliti akan mengambil sampel sebagai subjek penelitian. Sampel dipilih dengan teknik simple random sampling. Pada teknik simple random sampling, anggota sampel dipilih secara acak tanpa memperhatikan strata yang ada pada populasi (Sugiyono, 2013). Penarikan sampel menggunakan rumus Slovin:

Jumlah populasi mahasiswa aktif Universitas Kristen Petra tahun 2017 yaitu sebanyak 7.762 orang.

$$
n=\frac{N}{1+N(e)^{2}}
$$

Keterangan:

$n$ adalah ukuran sampel

$\mathrm{N}$ adalah jumlah populasi. Dalam penelitian ini populasi adalah mahasiswa aktif Universitas Kristen Petra pada tahun 2017 yaitu sebanyak 7.762 orang. e adalah persentase kesalahan yang ditolerir dalam pengambilan sampel. Dalam penelitian ini menggunakan $\mathrm{e}=7 \%(0.7)$

$$
n=\frac{7.762}{1+7.762(0.07)^{2}}
$$

$\mathrm{n}=199$ orang dibulatkan menjadi 200.

Dalam penelitian ini kuesioner dibagikan kepada mahasiswa Universitas Kristen Petra yang tersebar di 23 Program Studi. Jumlah sampel yang didapatkan adalah 200 orang. Pembagian kuesioner dilakukan pada bulan Maret 2018.

\section{HASIL DAN PEMBAHASAN}

\subsection{Data responden}

Di dalam penelitian ini, terdapat 200 orang responden, yang terdiri atas 103 orang laki-laki (51\%) dan 97 orang perempuan (49\%). Responden merupakan mahasiswa aktif Universitas Kristen Petra dari angkatan 2015 sebanyak 8 orang (4\%), angkatan 2016 sebanyak 72 orang (36\%), angkatan 2017 sebanyak 42 orang (21\%), dan angkatan 2018 sebanyak 78 orang (39\%). Responden dalam penelitian berasal dari 23 program studi yang ada di Universitas Kristen Petra.

Penentuan sampel yang dilakukan dalam penelitian ini bertujuan untuk melakukan pemerataan program studi yang ada di Universitas Kristen Petra. Selain program studi dan jenis kelamin yang beragam, responden juga berasal dari 4 angkatan yang masih menjadi mahasiswa aktif saat kuesioner dibagikan yaitu 2015-2018. Hal ini diharapkan dapat mewakili keseluruhan mahasiswa yang ada di Universitas Kristen Petra. Keberagaman menjadi hal yang utama dalam penentuan sampel pada penelitian ini karena tujuan yang ingin dicari adalah pola penggunaan media sosial pada mahasiswa Universitas Kristen Petra. Hasil penelitian ini diharapkan dapat mewakili keseluruhan mahasiswa Universitas Kristen Petra yang berjumlah lebih dari 7.762 mahasiswa.

\subsection{Media Sosial yang Diteliti}

Menurut data dari Hootsuite dan We Are Social yang dikeluarkan pada Januari 2019, presentase pengguna internet yang menggunakan social network yaitu YouTube $88 \%$, Facebook $81 \%$, Instagram $80 \%$, Twitter 52\%, LinkedIn 33\%, dan media sosial lain dibawah $30 \%$. Data tersebut yang menjadi dasar dalam penentuan media sosial yang ditanyakan kepada, yaitu Facebook, Instagram, Twitter, LinkedIn, dan YouTube. 
Facebook merupakan media sosial yang diluncurkan pertama kali pada Februari 2004 di Amerika Serikat. Media sosial ini mempunyai misi "Give people the power to build community and bring the world closer together." Dalam website-nya Facebook menunjukkan misinya yaitu memberdayakan lebih dari 2 miliar orang di seluruh dunia untuk berbagi ide, menawarkan dukungan, dan membuat perbedaan ("Company info", n.d).

Instagram merupakan media sosial yang diluncurkan pada Oktober 2010. Fungsinya, mencari dan membagikan foto, video, live video, serta bentuk konten lainnya, seperti yang tertera pada tampilan awal.

Twitter pertama kali diluncurkan pada Maret 2006. Twitter merupakan microblogging dan media sosial untuk menjalin relasi.

LinkedIn merupakan media sosial yang diluncurkan pertama kali pada Desember 2002. LinkedIn memungkinkan perusahaan, karyawan, dan para pencari kerja saling terhubung.

YouTube adalah platform media sosial yang diluncurkan pertama kali Februari 2005, dan memungkinkan penggunanya saling berbagi video.

\subsection{Kepemilikan Akun Media Sosial}

Dalam penelitian ini kuesioner dibagikan kepada 200 mahasiswa Universitas Kristen Petra dari berbagai angkatan dan program studi. Terdapat 194 orang responden (97\%) yang memiliki akun Instagram, dan 6 responden (3\%) tidak memiliki akun Instagram. Sejumlah 154 orang (77\%) memiliki akun Facebook, dan 46 responden (23\%) tidak memiliki akun Facebook. 99 orang responden (50\%) yang memiliki akun Twitter, dan 101 orang (50\%) yang tidak memiliki akun Twitter. Sebanyak 33 orang responden (17\%) memiliki akun LinkedIn, dan 167 orang (83\%) tidak memiliki akun LinkedIn.

Sedikit berbeda dengan YouTube karena tanpa memiliki akun, sudah dapat mengakses media sosial tersebut. Perbedaannya jika memiliki YouTube channel maka orang dapat mengupload video dan dapat ditonton oleh orang yang lain. Dalam penelitian ini ada 171 orang responden (86\%) yang mengakses YouTube dan 29 orang (14\%) tidak mengakses YouTube. Sedangkan 91 orang responden (46\%) yang memiliki YouTube channel dan 101 orang tidak memiliki YouTube channel.
Hasil penelitian menunjukkan mayoritas responden memiliki akun Instagram, Facebook, dan YouTube. Menurut data Hootsuite dan We Are Social yang dirilis pada tahun 2018 menunjukkan data pengguna aktif media sosial di Indonesia sebanyak 130 juta dengan penetrasi $49 \%$. Sedangkan pertumbuhan pengguna media sosial di Indonesia sebesar $23 \%$ dalam satu tahun terakhir.

Pertumbuhan pengguna media sosial tersebut berpengaruh pada berbagai hal khususnya komunikasi. Media sosial menjadi media baru dalam berkomunikasi. Banyak yang beralih ke media sosial karena kecepatan informasi yang membuat orang dapat mengaksesnya dari mana saja dan kapan saja. Perusahaan maupun organisasi juga dapat memanfaatkan media sosial untuk melakukan promosi mengingat pertumbuhan media sosial yang meningkat setiap tahunnya. Dalam dunia pendidikan, media sosial tentu saja dapat dimanfaatkan untuk menyebarkan informasi maupun untuk calon murid yang ingin mengetahui segala hal tentang lembaga pendidikan tersebut.

\subsection{Lama Penggunaan Media Sosial}

Seluruh responden yang memiliki akun media sosial akan diberi pertanyaan berikutnya tentang berapa lama penggunaan media sosial tersebut. 154 Responden yang memiliki akun Facebook, ada sebanyak 144 orang (94\%), mengakses Facebook kurang dari satu jam. Kemudian, 7 orang (5\%) mengakses selama 1-2 jam. Terdapat 2 orang (1\%) mengakses selama 2-3 jam, dan 1 orang lainnya (1\%) mengakses Facebook selama lebih dari tiga jam.

Dari 194 Responden yang memiliki akun Instagram, ada 80 orang $(41 \%)$ menggunakan Instagram lebih dari tiga jam. Kemudian, terdapat 54 orang (28\%) menggunakan Instagram 2-3 jam dan 50 orang (26\%) lainnya menggunakan Instagram selama 1-2 jam. Hanya terdapat 10 orang (5\%) yang mengakses Instagram kurang dari satu jam. Responden yang memiliki akun Twitter sebanyak 99 orang, ada 85 orang (86\%), menggunakan Twitter kurang dari satu jam. Terdapat 9 orang $(9 \%)$ yang mengakses Twitter 1-2 jam, 4 orang (4\%) menggunakan Twitter 2-3 jam, dan hanya satu orang (1\%) yang memanfaatkan Twitter lebih dari 3 jam.

33 responden yang memiliki akun LinkedIn ada 31 orang (94\%) mengakses LinkedIn kurang dari 1 jam. Hanya 2 orang (6\%) yang menggunakan LinkedIn 12 jam. 
Sebanyak 171 responden yang mengakses YouTube, terdapat 61 orang $(36 \%)$ menggunakan YouTube lebih dari tiga jam. Kemudian, terdapat 46 orang (27\%) yang memanfaatkan YouTube selama 2-3 jam, 49 orang (29\%) memanfaatkan YouTube selama 1-2 jam, dan 15 orang (9\%) memanfaatkan YouTube selama kurang dari satu jam.

Hasil penelitian didukung oleh data dari Hootsuite dan We Are Social yang dikeluarkan pada Januari 2019 mengenai rata-rata waktu yang dihabiskan oleh masyarakat Indonesia untuk menggunakan media sosial melalui berbagai peralatan yaitu 3 jam 23 menit per hari. Penggunaan media sosial menjadi suatu hal yang tidak dapat dipisahkan dalam keseharian masyarakat. Perubahan komunikasi yang awalnya tatap muka (face-to-face) saat ini telah beralih ke media sosial.

Mayoritas responden pengguna Instagram mengakses lebih dari tiga jam per hari, hal ini disebabkan banyaknya fitur yang dapat digunakan penggunanya. Pengguna Instagram dapat berbagi foto dan video, serta melihat foto dan video dari orang yang di-follow. Selain itu, terdapat fitur explore di mana pengguna dapat melihat foto dan video sesuai minatnya masingmasing. Masih ada fitur Instagram Story, di mana pengguna dapat berbagi maupun melihat cerita dari orang lain. Banyaknya fitur tersebut membuat pengguna dapat menggunakan akses Instagram lebih dari tiga jam setiap harinya.

Hal tersebut juga berlaku untuk YouTube, di mana media sosial ini memiliki jutaan video yang dapat dieksplor oleh penggunanya. Pada YouTube, pengguna dapat memilih video mana yang ingin ditonton sesuai minat. Setiap video memiliki durasi yang berbeda-beda, sehingga hal ini menyebabkan seseorang bisa melihat video sampai berjam-jam. Inilah yang memicu responden dalam penelitian ini mengakses YouTube hingga lebih dari 3 jam per hari.

Facebook adalah media sosial yang juga memiliki berbagi fitur yang dapat dimanfaatkan. Seperti berbagai foto, video, status hingga ucapan. Meski banyak responden yang menggunakan Facebook, 158 orang $(93,49 \%)$ mengakses kurang dari satu jam setiap harinya.

\subsection{Waktu penggunaan media sosial.}

Dari 154 responden yang memiliki akun Facebook, 110 orang $(71 \%)$ tidak memiliki waktu yang pasti dalam menggunakan media sosial, dan 20 orang
(13\%) mengakses media sosial setiap ada waktu. Selanjutnya, terdapat 13orang (8\%) menggunakan media sosial saat malam, 4 orang (3\%) saat sore, 5 orang (3\%) saat siang, dan 2 orang (1\%) memanfaatkan media sosial saat pagi.

194 responden yang memiliki akun Instagram, terdapat 86 orang (44\%) yang menggunakan Instagram setiap ada kesempatan. Sebanyak 84 orang (43\%) tidak memiliki waktu yang pasti untuk mengakses media sosial. Lalu, 16 orang (8\%) mengakses media sosial saat malam hari, 4 orang (2\%) mengakses saat sore hari, 3 orang $(2 \%)$ mengakses saat saat siang hari, dan 1 orang (1\%) mengakses media sosial saat pagi hari.

99 responden yang memiliki akun Twitter, ada 75 orang $(76 \%)$ tidak memiliki waktu yang pasti untuk menggunakan media sosial. 16 orang $(16 \%)$ menggunakan media sosial setiap kali ada waktu. 4 orang (4\%) menggunakan media sosial saat malam hari, 3 orang (3\%) saat sore hari, dan 1 orang lainnya (1\%) menggunakannya saat pagi hari. Sedangkan, tidak ada yang menggunakan Twitter saat sore hari.

Responden yang memiliki akun LinkedIn sebanyak 33 orang, ada 21 orang (64\%) tidak memiliki waktu yang pasti untuk menggunakan LinkedIn. 8 orang (24\%) menggunakan media sosial setiap ada waktu. 2 orang $(6 \%)$ menggunakan media sosial saat siang, 1 orang (3\%) menggunakan saat malam, dan 1 orang (3\%) menggunakan LinkedIn saat pagi.

171 responden yang mengakses YouTube ada sebanyak 63 orang (37\%) yang tidak memiliki waktu pasti dalam menggunakan YouTube. 58 orang (34\%) menggunakan YouTube setiap ada waktu. Kemudian, terdapat 43 orang (25\%) menggunakan YouTube saat malam, 4 orang (2\%) menggunakan saat sore, 2 orang (1\%) menggunakan saat siang, dan 1 orang (1\%) menggunakan YouTube saat pagi.

Dari hasil penelitian, mayoritas responden tidak memiliki waktu yang pasti dalam mengakses media sosial hal ini terjadi di pemilik akun Facebook, Twitter dan LinkedIn. Sedangkan pemilik akun Instagram mayoritas mengakses setiap ada waktu yaitu sebesar 45,29\%. Hal ini menunjukkan responden akan membuka aplikasi Instagram setiap ada waktu yang memungkinkan. Sedangkan untuk YouTube, mayoritas responden tidak memiliki waktu yang pasti untuk mengakses dan akan membuka setiap ada kesempatan. 
Responden yang merupakan mahasiswa Universitas Kristen Petra mayoritas akan membuka media sosial setiap ada kesempatan. Hal ini menunjukkan bahwa setiap tidak ada hal yang dikerjakan maka mahasiswa akan langsung mengakses media sosial. Oleh sebab itu media sosial dapat dimanfaatkan untuk melakukan berkomunikasi maupun menyampaikan pesan khususnya untuk mahasiswa.

\subsection{Penggunaan Media Sosial untuk Mencari Informasi}

Seluruh responden yang memiliki akun media sosial akan diberi pertanyaan tentang "Apakah media sosial tersebut dipergunakan untuk mencari informasi?" Hasil jawaban dan persentase yang didapatkan menyesuaikan dengan jumlah pemilik akun, data berikut diurutkan berdasarkan persentase bukan jumlah responden.

Untuk mencari informasi responden menggunakan Instragram sebanyak 170 orang (88\%), YouTube sebanyak 151 orang $(88 \%)$, LinkedIn sebanyak 22 orang $(67 \%)$, Twitter sebanyak 22 orang $(67 \%)$ dan Facebook sebanyak 89 orang (58\%).

Munculnya internet dapat menghubungkan antar manusia dari berbagai belahan dunia yang tidak saling kenal sebelumnya dengan cara mengkoneksikan komputer dengan jaringan internet. Interaksi antar manusia tersebut bertujuan memenuhi kebutuhan hidup, baik kebutuhan jasmani maupun rohani. Salah satunya, kebutuhan akan informasi. Setiap orang membutuhkan informasi sebagai bagian dari tuntutan kehidupan dan sebagai penunjang kegiatannya. Internet sangat bermanfaat bagi pemenuhan kebutuhan akan informasi tersebut (Alyusi, 2016, p.1).

Kebutuhan akan informasi membuat responden mencari sumber yang paling dapat memenuhi kebutuhannya. Selain dimiliki oleh banyak responden, Instagram juga dianggap sebagai sumber informasi. Hal ini didukung oleh berbagai fitur yang dapat dimanfaatkan di Instagram. Saat ini, perusahaan, organisasi, maupun media telah memiliki akun Instagram, dan dimanfaatkan berbagi informasi. Oleh sebab itu, Instagram menjadi alternatif responden mencari informasi.

Selain Instagram, media yang digunakan mencari informasi adalah YouTube. Pengguna dapat memilih informasi yang ingin didapatkan karena banyaknya video yang tersedia di YouTube. Twitter juga menjadi pilihan responden dalam mencari informasi. Hal ini ditunjang oleh sifat Twitter yang real-time. Dengan Twitter, pengguna dapat saling berbagi informasi melalui 280 karakter. Meski begitu, hanya sedikit responden yang menyukai keunggulan ini karena isinya cenderung singkat, padat dan jelas.

\subsection{Penggunaan Media Sosial untuk Mencari Hiburan}

Seluruh responden yang memiliki akun media sosial akan diberi pertanyaan tentang "Apakah media sosial tersebut dipergunakan untuk mencari hiburan?" Hasil jawaban dan persentase yang didapatkan menyesuaikan dengan jumlah pemilik akun, data berikut diurutkan berdasarkan persentase bukan jumlah responden.

Untuk mencari hiburan responden menggunakan YouTube sebanyak 161 orang (94\%), Instragram sebanyak 173 orang (89\%), Twitter sebanyak 50 orang (51\%) dan Facebook sebanyak 60 orang (39\%), LinkedIn sebanyak 1 orang (3\%).

YouTube merupakan media yang bersifat video sharing memungkinkan pengguna memilih video yang ingin ditonton. Bahkan untuk menonton, pengguna tidak perlu memiliki akun tersendiri, pengguna cukup memiliki akun Google Mail. Bahkan, saat ini media massa televisi juga memiliki YouTube Channel. Alhasil, penonton masih dapat menonton program televisi tersebut kapan saja.

Instagram dan Twitter juga menjadi media sosial yang menjadi alternatif responden untuk mencari hiburan. Banyak artis maupun publik figur yang memiliki akun Instagram dan Twitter, serta memanfaatkan kedua media sosial tersebut untuk berkomunikasi dengan penggemarnya. Hal tersebut menjadi salah satu kelebihan yang dimiliki media sosial yang selama ini tidak di miliki media massa. Oleh sebab itu responden menggunakan media sosial Instagram dan Twitter untuk mencari hiburan.

\subsection{Penggunaan Media Sosial untuk melakukan Networking}

Seluruh responden yang memiliki akun media sosial akan diberi pertanyaan tentang "Apakah media sosial tersebut dipergunakan untuk melakukan networking?" Hasil jawaban dan persentase yang didapatkan menyesuaikan dengan jumlah pemilik akun, data berikut diurutkan berdasarkan persentase bukan jumlah responden. 
Untuk melakukan networking responden menggunakan Instragram sebanyak 129 orang (66\%), LinkedIn sebanyak 16 orang (48\%), Facebook sebanyak 55 orang (36\%), Twitter sebanyak 24 orang (24\%) dan YouTube sebanyak 26 orang (15\%).

Instagram yang awalnya hanya berfungsi photo sharing telah mengembangkan fiturnya. Kini, pengguna untuk dapat memberi feedback terhadap posting yang ada. Feedback tersebut dapat berupa like, memberikan komentar bahkan bisa me-repost posting yang ada, pengguna juga bisa menggunakan DM (Direct Message) yang berfungsi seperti chat. Hal ini dapat membuat responden menggunakan Instagram untuk selalu menjaga hubungan dengan orang lain.

Internet juga menawarkan kesempatan bagi pengguna untuk mengembangkan hubungan pribadi dengan orang lain, bahkan berbagi identitas. Meskipun komunikasi online merupakan bentuk komunikasi tanpa tatap muka dan hanya menggunakan teks, namun pengguna masih bisa menyampaikan berbagai emosi dari kebahagiaan dan kasih sayang, kemarahan dan permusuhan dengan penggunaan berbagai macam emoticon dan teknik pemformatan (Alyusi, 2016:6).

Pengguna LinkedIn dalam penelitian ini sedikit. Namun, sebanyak $45,71 \%$ responden menggunakannya untuk menjalin hubungan atau networking. Salah satu fasilitas LinkedIn adalah kemampuan pengguna melihat data pengguna lain. Bahkan, pengguna juga dapat saling terkoneksi satu dengan lainnya, khususnya di bidang yang sama. Networking yang terjadi di LinkedIn bersifat profesional, berbeda dengan media sosial lainnya. Hal ini dianggap berguna khususnya bagi mahasiswa yang akan melamar pekerjaan.

\subsection{Penggunaan Media Sosial untuk Menambah Ilmu}

Seluruh responden yang memiliki akun media sosial akan diberi pertanyaan tentang "Apakah media sosial tersebut dipergunakan untuk menambah ilmu?" Hasil jawaban dan persentase yang didapatkan menyesuaikan dengan jumlah pemilik akun, data berikut diurutkan berdasarkan persentase bukan jumlah responden.

Untuk menambah ilmu responden menggunakan Instragram sebanyak 112 orang (58\%), LinkedIn sebanyak 10 orang (30\%), Facebook sebanyak 41 orang (27\%), Twitter sebanyak 24 orang (24\%) dan YouTube sebanyak 132 orang (77\%).
William Martin (1995) dalam bukunya yang berjudul The Global Information Society, mendefinisikan masyarakat informasi sebagai suatu masyarakat dimana kualitas hidup dan juga prospek untuk perubahan sosial dan pembangunan ekonomi tergantung pada peningkatan informasi dan pemanfaatannya. Dalam masyarakat seperti ini, standar hidup, polapola kerja, kesenangan, sistem pendidikan, dan pemasaran barang-barang sangat dipengaruhi oleh akumulasi peningkatan informasi dan pengetahuan. Hal ini dibuktikan dengan meningkatnya intensitas produksi informasi dan pelayanan, komunikasi yang luas melalui media dan banyak diantaranya dilakukan secara elektronis (Alyusi, 2016, p.24-25).

YouTube menjadi pilihan responden untuk menambah ilmu. Kemampuan YouTube yang memudahkan penggunanya untuk mencari berbagai jenis video sesuai dengan minat membuat YouTube dipilih responden untuk menambah ilmu.

Instagram dan Facebook juga menjadi pilihan responden untuk menambah ilmu, walau masih lebih sedikit dibandingkan YouTube. Kedua media sosial memang memiliki fasilitas video yang dapat menunjukkan tutorial untuk belajar namun durasinya tidak sepanjang YouTube. Selain itu, penyedia video harus dapat menyesuaikan materi yang akan diberikan dengan durasi yang tersedia. Hal ini menyebabkan banyaknya responden yang menggunakan Instagram dan Facebook untuk menambah ilmu karena durasi tidak terlalu panjang.

\subsection{Penggunaan Media Sosial pada Mahasiswa Universitas Kristen Petra}

Mayoritas mahasiswa Universitas Kristen Petra memiliki akun Instagram, meskipun ada lima media sosial yang diteliti namun jumlahnya lebih sedikit dibandingkan pemilik Instagram. Mahasiswa menggunakan media sosial kapan saja ada di mana saja setiap ada kesempatan dengan rata-rata 1-3 jam tergantung media sosial mana yang digunakan. Ketika menggunakan Facebook responden rata-rata hanya 1 jam per hari, namun saat menggunakan Instagram dapat lebih dari 3 jam.

Penggunaan media sosial pun sesuai dengan fasilitas dan kegunaan masing-masing media. Responden akan menggunakan Instagram dan YouTube saat akan mencari informasi maupun untuk mencari hiburan. Saat akan melakukan networking, responden akan memilih Instagram dan LinkedIn. Sedangkan untuk menambah ilmu, YouTube menjadi pilihan responden. 
Media sosial dapat dimanfaatkan oleh lembaga pendidikan maupun perusahaan dan organisasi lainnya untuk menyampaikan pesan khususnya untuk generasi milenial. Hanya saja harus dapat memilih media yang sesuai dengan pesan yang ingin disampaikan. Sehingga peralihan komunikasi dari face-to-face ke media tetap dapat memperlancar komunikasi khususnya untuk generasi milenial di mana sebagian besar waktunya dihabiskan untuk mengakses media sosial.

\section{KESIMPULAN}

Mahasiswa merupakan generasi milenial yang tidak bisa lepas dari perangkat mobile untuk pencarian informasi, pembelian online, dan berinteraksi dengan lain serta mencari hiburan. Dalam penelitian ini ingin mengetahui tentang pola penggunaan media sosial pada mahasiswa Universitas Kristen Petra.

Melalui penelitian ini didapatkan hasil bahwa, media sosial yang paling banyak digunakan mahasiswa adalah Instagram. Responden tidak memiliki waktu khusus untuk mengakses media sosial, bahkan setiap ada kesempatan mahasiswa akan membuka akun media sosial. Melalui pola penggunaan ini, dapat diketahui bahwa mahasiswa menggunakan media sosial khususnya Instagram lebih dari tiga jam per hari. Hal ini dapat menjadi salah satu alternatif jika media tersebut digunakan menjaga hubungan komunikasi dengan mahasiswa.

Fungsi media massa mulai beralih ke media sosial, yaitu mencari informasi, mencari hiburan, dan menambah ilmu. Ketiga fungsi tersebut didapatkan responden melalui media sosial Instagram, YouTube dan Facebook. Media sosial ini memiliki berbagai fitur yang dapat memenuhi kebutuhan penggunanya sehingga dapat mengakses dari mana saja dan kapan saja. Sedangkan, fungsi menjalin hubungan atau networing, terdapat dua jenis media sosial yang dapat dimanfaatkan. Dalam membina hubungan personal, mayoritas responden menggunakan Instagram dan Facebook, sedangkan untuk hubungan profesional, responden memilih LinkedIn. Kesimpulan dari penelitian ini adalah media sosial Instagram dapat menjadi pilihan untuk Universitas Kristen Petra dalam membina komunikasi dengan mahasiswanya.

\section{DAFTAR PUSTAKA}

Abadi, S. (1994). Marketing public relations: Upaya memenangkan persaingan. Jakarta: Lembaga Management Feui.
Alyusi, S.D. (2016). Media sosial: Interaksi, identitas, dan modal sosial. Jakarta: Prenadamedia.

Blythe, J. (2006). Essentials of Marketing Communications, 3rd edition. London: Pearson Education Ltd.

About Facebook. (n.d.). Company Info. Retrieved from https://about.fb.com/company-info/

Brogan, C. (2011). Social media 101: Tactics and tips to develop your business online. New York: John Wiley \& Sons.

Cultip, S.M. (2007). Effective public relations, 9th edition. Jakarta: Kencana.

Digital in 2019. (n.d.). We are social. Retrieved November 21, 2019, from https://wearesoci al.com/global-digital-report-2019

Gilmor, D. (2004). We the media: Grassroots journalism by the people, for people. Sebastopol, CA: O'Reilly Media, Inc.

Harris, T.L. (1991). The marketer's guide to public relations. New York: Jhone Wiley \& Sons.

Indonesia digital 2019: Media sosial. (n.d.). Retrieved November 22, 2019, from https://websindo. com/indonesia-digital-2019-media-sosial/

Kriyantono, R. (2008). Teknik praktis riset komunikasi: Disertai contoh praktis riset media, public relations, advertising, komunikasi organisasi, komunikasi pemasaran. Jakarta: Prenada Media Group.

Mayfield, A. (2008). What is social media? USA: iCrossing.

Nasrullah, R. (2015). Media sosial: Prosedur, tren, dan etika. Bandung: Simbiosa Rekatama Media.

Neuman, W.L. (2013). Metode penelitian sosial: Pendekatan kualitatif dan kuantitatif, edisi ketujuh. Jakarta: PT Indeks.

Nurudin. (2007). Pengantar komunikasi massa. Jakarta: PT RajaGrafindo Persada.

Orang Indonesia peringkat 3 dunia yang paling sering bermedsos. (2019, May 2). Retrieved November 21, 2019, from https://katadata.co .id/grafik/2019/05/02/orang-indonesia-perin gkat-3-yang-paling-sering-bermedsos-didunia

Ruslan, R. (2002). Manajemen humas dan komunikasi. Jakarta: PT Raja Grafindo Persada.

Sugiyono. (2013). Metode penelitian kuantitatif, kualitatif, dan $R \& D$. Bandung: Alfabeta.

Student. (n.d.). Retrieved November 22, 2019, from http://petra.ac.id/pages/student

Taher, E. (2017, October 20). 4 Karakteristik millenial yang perlu diketahui bagian pemasaran. Retrieved November 22, 2019, from https://id. techinasia.com/4-karakteristik-millennial 
Theaker, A. (2001). The public relations handbook. London: Routledge.

Universitas Kristen Petra. (n.d.). Retrieved November 25, 2019, from https://ayokuliah.id/universitas/universitas-kristen-petra/
UK Petra raih akreditasi institusi $A$ dan anugerah kampus unggulan. (2018, December 4). Retrieved November 22, 2019, from https://dwipekan.petra.ac.id/2018/12/04/uk-petra-raihakreditasi-institusi-a-dan-anugerah-kampusunggulan/ 